\title{
The hydrogen sulfide donor, Lawesson's reagent, prevents alendronate-induced gastric damage in rats
}

\author{
L.A.D. Nicolau ${ }^{1}$, R.O. Silva ${ }^{2}$, S.R.B. Damasceno ${ }^{2}$, N.S. Carvalho ${ }^{2}$, N.R.D. Costa ${ }^{2}$, K.S. Aragão ${ }^{3}$ \\ A.L.R. Barbosa ${ }^{1,2}$, P.M.G. Soares ${ }^{3}$, M.H.L.P. Souza ${ }^{3}$ and J.V.R. Medeiros ${ }^{1,2}$ \\ ${ }^{1}$ Núcleo de Pesquisa em Produtos Naturais, Departamento de Farmacologia, Universidade Federal do Piauí, Teresina, PI, Brasil \\ ${ }^{2}$ Laboratório de Fisiofarmacologia Experimental, Centro de Pesquisa em Biodiversidade e Biotecnologia, \\ Universidade Federal do Piauí, Parnaíba, PI, Brasil \\ ${ }^{3}$ Laboratório de Farmacologia da Inflamação e do Câncer, Departamento de Farmacologia, \\ Universidade Federal do Ceará, Fortaleza, CE, Brasil
}

\begin{abstract}
Our objective was to investigate the protective effect of Lawesson's reagent, an $\mathrm{H}_{2} \mathrm{~S}$ donor, against alendronate (ALD)-induced gastric damage in rats. Rats were pretreated with saline or Lawesson's reagent $(3,9$, or $27 \mu \mathrm{mol} / \mathrm{kg}$, po) once daily for 4 days. After $30 \mathrm{~min}$, gastric damage was induced by ALD $(30 \mathrm{mg} / \mathrm{kg})$ administration by gavage. On the last day of treatment, the animals were killed $4 \mathrm{~h}$ after ALD administration. Gastric lesions were measured using a computer planimetry program, and gastric corpus pieces were assayed for malondialdehyde (MDA), glutathione (GSH), proinflammatory cytokines [tumor necrosis factor (TNF)- $\alpha$ and interleukin (IL)-1ß], and myeloperoxidase (MPO). Other groups were pretreated with glibenclamide $(5 \mathrm{mg} / \mathrm{kg}$, ip) or with glibenclamide ( $5 \mathrm{mg} / \mathrm{kg}$, ip) + diazoxide (3 mg/kg, ip). After $1 \mathrm{~h}, 27 \mu \mathrm{mol} / \mathrm{kg}$ Lawesson's reagent was administered. After $30 \mathrm{~min}$, $30 \mathrm{mg} / \mathrm{kg}$ ALD was administered. ALD caused gastric damage $\left(63.35 \pm 9.8 \mathrm{~mm}^{2}\right)$; increased levels of TNF- $\alpha$, IL-1 $\beta$, and MDA $(2311 \pm 302.3 \mathrm{pg} / \mathrm{mL}, 901.9 \pm 106.2 \mathrm{pg} / \mathrm{mL}, 121.1 \pm 4.3 \mathrm{nmol} / \mathrm{g}$, respectively); increased MPO activity $(26.1 \pm 3.8 \mathrm{U} / \mathrm{mg}) ;$ and reduced GSH levels $(180.3 \pm 21.9 \mu \mathrm{g} / \mathrm{g})$. ALD also increased cystathionine- $\gamma$-lyase immunoreactivity in the gastric mucosa. Pretreatment with Lawesson's reagent $(27 \mu \mathrm{mol} / \mathrm{kg})$ attenuated ALD-mediated gastric damage $\left(15.77 \pm 5.3 \mathrm{~mm}^{2}\right)$; reduced TNF$\alpha, \mathrm{IL}-1 \beta$, and MDA formation (1502 $\pm 150.2 \mathrm{pg} / \mathrm{mL}, 632.3 \pm 43.4 \mathrm{pg} / \mathrm{mL}, 78.4 \pm 7.6 \mathrm{nmol} / \mathrm{g}$, respectively); lowered MPO activity $(11.7 \pm 2.8 \mathrm{U} / \mathrm{mg})$; and increased the level of $\mathrm{GSH}$ in the gastric tissue $(397.9 \pm 40.2 \mu \mathrm{g} / \mathrm{g})$. Glibenclamide alone reversed the gastric protective effect of Lawesson's reagent. However, glibenclamide plus diazoxide did not alter the effects of Lawesson's reagent. Our results suggest that Lawesson's reagent plays a protective role against ALD-induced gastric damage through mechanisms that depend at least in part on activation of ATP-sensitive potassium $\left(\mathrm{K}_{\text {ATP }}\right)$ channels.
\end{abstract}

Key words: Alendronate; Lawesson's reagent; $\mathrm{H}_{2} \mathrm{~S}$ donors; Gastric damage

\section{Introduction}

The discovery and development of bisphosphonates have been of great clinical importance for the prevention and treatment of bone diseases. Among the various bisphosphonates used clinically, those with primary amino side chains, such as alendronate (ALD) and pamidronate, may also have increased potential for causing gastric damage (1-4).

The most common adverse effects related to ALD use are acute upper gastrointestinal bleeding, abdominal pain, and discomfort (5). ALD use is also associated with irritant effects on the esophagus, stomach, and duodenum $(6,7)$. However, the mechanism underlying ALD-mediated toxicity is unknown.
Hydrogen sulfide $\left(\mathrm{H}_{2} \mathrm{~S}\right)$ is a well-known toxic gas. Toxicity of $\mathrm{H}_{2} \mathrm{~S}$ is observed at concentrations well above those produced endogenously and is usually associated with the presence of high concentrations in the lung and blood $(8,9)$. Given the potential toxicity of this gas, efficient systems exist to metabolize and scavenge $\mathrm{H}_{2} \mathrm{~S}$ in vivo. $\mathrm{H}_{2} \mathrm{~S}$ is metabolized by oxidation in mitochondria or by methylation in cytosol (10).

$\mathrm{H}_{2} \mathrm{~S}$ is synthesized endogenously from L-cysteine by two enzymes: cystathionine- $\gamma$-lyase (CSE) and cystathionine- $\beta$-synthetase (CBS) (10). CSE is the main enzymatic source of $\mathrm{H}_{2} \mathrm{~S}$ in the vasculature and heart, and CBS predominates in the central nervous system $(10,11)$.

Correspondence: J.V.R. Medeiros, LAFFEX/BIOTEC/UFPI, Av. São Sebastião, 2819, 64202-020 Parnaíba, PI, Brasil. Fax: + 55-863323-5406. E-mail: jandvenes@ufpi.edu.br 
Both enzymes are expressed in the gastric mucosa $(12,13)$.

Results from recent reports suggest that $\mathrm{H}_{2} \mathrm{~S}$ protects against mucosal injury. NaHS and Lawesson's reagent, both $\mathrm{H}_{2} \mathrm{~S}$ donors, reduce the gastric damage induced by ethanol (13) and nonsteroidal anti-inflammatory drugs (NSAIDs) in rats (14). Furthermore, $\mathrm{H}_{2} \mathrm{~S}$ donors participate in ulcer repair, regulate gastric mucosal blood flow, and contribute to the maintenance of gastric mucosal integrity $(12,15,16)$. However, the role of $\mathrm{H}_{2} \mathrm{~S}$ in ALDinduced gastric damage is unknown.

Because there is still no curative therapy for gastropathy caused by ALD and there are few studies on the mechanisms involved in its toxicity, the aim of this study was to evaluate the gastroprotective effect of Lawesson's reagent, an $\mathrm{H}_{2} \mathrm{~S}$ donor, against ALD-induced gastric damage in rats, and the possible mechanisms.

\section{Material and Methods}

\section{Animals}

Female Wistar rats, weighing 180-200 g, were obtained from Departamento de Fisiologia e Farmacologia, Universidade Federal do Ceará, Fortaleza, CE, Brazil. The animals were housed in cages in a temperature-controlled environment under a 12:12-h light-dark cycle. The animals had free access to drinking water and a standard pellet diet (Purina chow, Brazil). The animals were deprived of food for 18-24 $\mathrm{h}$ before the experiment, but had free access to water. All animal treatments and surgical procedures were performed in accordance with the Guide for Care and Use of Laboratory Animals (National Institutes of Health, Bethesda, MD, USA) and were approved by the Ethics Committee of Universidade Federal de Piauí (Protocol No. 0067/10).

\section{Drugs and solutions}

Lawesson's reagent, glibenclamide, and ALD were purchased from Sigma (USA). Vehicle solutions consisted of saline. ALD was dissolved in saline and adjusted to $\mathrm{pH} 7.0$ by adding $\mathrm{NaOH}$ or $\mathrm{HCl}$ (15). Glibenclamide was dissolved in $0.01 \mathrm{~N} \mathrm{NaOH}$ containing $4 \%$ glucose.

\section{$\mathrm{H}_{2} \mathrm{~S}$ donor and ALD-induced gastric damage}

The animals $(n=5)$ were initially treated with Lawesson's reagent $\left(\mathrm{H}_{2} \mathrm{~S}\right.$ donor: 3,9 , or $27 \mu \mathrm{mol} / \mathrm{kg}$, po) or an equivalent volume of their respective vehicle. After $30 \mathrm{~min}$, the rats received ALD (30 mg/kg, $\mathrm{pH} 7.0$ ) by gavage. All drugs were administered once daily for 4 days (16). On the last day of treatment, $4 \mathrm{~h}$ after ALD administration, the animals were killed and their stomachs removed. Gastric damage was measured using a computer planimetry program (Image $\mathrm{J}^{\mathbb{R}}$, USA). A sample of the stomach was fixed in $10 \%$ formalin immediately after its removal for subsequent histopathological assessment. Other samples of the stomach were then weighed, frozen, and stored at $-70^{\circ} \mathrm{C}$ until assayed for glutathione (GSH) (17), malondialdehyde (MDA) (18), myeloperoxidase (MPO) activity (19), and cytokine concentrations (20).

\section{Histological evaluation of gastric lesions}

For histological evaluation, stomach samples were fixed in $10 \%$ formalin solution, where they remained for $24 \mathrm{~h}$. After this procedure, the samples were transferred to a solution of $70 \%$ alcohol. Then, the samples were embedded in paraffin and sectioned. Four-micrometerthick sections were deparaffinized, stained with hematoxylin and eosin, and then examined under a microscope. The specimens were assessed according to the criteria of Laine and Weinstein (21), who assigned scores according to the following parameters: epithelial cell loss (a score of 0-3), edema in the upper mucosa (a score of 0-4), hemorrhagic damage (a score of $0-4$ ), and presence of inflammatory cells (a score of 0-3), yielding a maximum total score of 14 . Afterward, the sections were assessed by an experienced pathologist who was blinded to the treatment.

\section{Role of ATP-sensitive potassium ( $\mathrm{K}_{\mathrm{ATP}}$ ) channels in Lawesson's reagent-mediated gastric protection}

To study the role of $\mathrm{K}_{\mathrm{ATP}}$ in Lawesson's reagentmediated gastric protection, animals $(n=5)$ were pretreated with glibenclamide $(5 \mathrm{mg} / \mathrm{kg}, i p)$, a drug that blocks $\mathrm{K}_{\mathrm{ATP}}$-dependent channels, or with glibenclamide $(5 \mathrm{mg} / \mathrm{kg}, i p)+$ diazoxide $(3 \mathrm{mg} / \mathrm{k}, i p)$. After $1 \mathrm{~h}$, the rats received Lawesson's reagent $(27 \mu \mathrm{mol} / \mathrm{kg})$. After $30 \mathrm{~min}$, the rats received ALD (30 mg/kg, $\mathrm{pH} 7.0)$ by gavage. All drugs were administered once daily for 4 days. On the last day of treatment, $4 \mathrm{~h}$ after ALD administration, gastric damage was determined as described earlier.

\section{Glutathione analysis}

The reduced GSH content of stomach tissues was estimated according to the method described by Sedlak and Lindsay (17). Briefly, 50-100 mg frozen gastric tissue was homogenized in $1 \mathrm{~mL} 0.02 \mathrm{M}$ EDTA for each $100 \mathrm{mg}$ tissue. Aliquots $(400 \mu \mathrm{L})$ of the homogenate were mixed with $320 \mu \mathrm{L}$ distilled water and $80 \mu \mathrm{L} 50 \%(\mathrm{w} / \mathrm{v})$ trichloroacetic acid to precipitate proteins. The tubes were centrifuged at $3000 \mathrm{~g}$ for $15 \mathrm{~min}$ at $4^{\circ} \mathrm{C}$. Supernatants $(400 \mu \mathrm{L})$ were mixed with $800 \mu \mathrm{L}$ Tris buffer $(0.4 \mathrm{M}, \mathrm{pH}$ 8.9) and $20 \mu \mathrm{L}$ 5,5'-dithiobis(2-nitrobenzoic acid) (0.01 M). The mixture was then stirred for $3 \mathrm{~min}$ and the absorbance was read at $412 \mathrm{~nm}$ using a spectrophotometer. The results are reported as micrograms of GSH per gram of tissue $(\mu \mathrm{g} / \mathrm{g})$.

\section{MDA analysis}

The level of MDA in the homogenates from each group was measured using the method of Mihara and Uchiyama (18), which is based on the reaction with thiobarbituric acid. Fragments of gastric mucosa weighing between 100 and $150 \mathrm{mg}$ were homogenized in cold $\mathrm{KCl}$ $(1.15 \%)$ to prepare a $10 \%$ solution of homogenate. Briefly, 
$250 \mu \mathrm{L}$ of this homogenate was added to $1.5 \mathrm{~mL} 1 \%$ $\mathrm{H}_{3} \mathrm{PO}_{4}$ and $0.5 \mathrm{~mL} 0.6 \%$ thiobarbituric acid (aqueous solution). Then, the mixture was stirred and heated in a boiling water bath for $45 \mathrm{~min}$. Next, the reaction mixture was cooled immediately in an ice water bath, followed by addition of $4 \mathrm{~mL} n$-butanol. This mixture was shaken for $1 \mathrm{~min}$, and the butanol layer was separated by centrifugation at $1,200 \mathrm{~g}$ for $10 \mathrm{~min}$. Absorbance was determined at 535 and $520 \mathrm{~nm}$, and the absorbance difference between the two determinations was calculated and considered as the thiobarbituric acid value. MDA concentrations are reported as nanomoles per gram of tissue $(\mathrm{nmol} / \mathrm{g})$.

\section{MPO activity}

MPO is an enzyme found primarily in neutrophil azurophilic granules. It has been used extensively as a biochemical marker for granulocyte infiltration into various tissues, including the gastrointestinal tract. The extent of neutrophil accumulation in the gastric mucosa was measured by MPO activity evaluation as previously described (19). Briefly, 50-100 mg tissue was homogenized in $1 \mathrm{~mL}$ potassium phosphate buffer $(50 \mathrm{mM}, \mathrm{pH} 6.0)$ with $0.5 \%$ hexadecyltrimethylammonium bromide for each $50 \mathrm{mg}$ tissue. Then, homogenates were centrifuged at $40,000 \mathrm{~g}$ for $7 \mathrm{~min}$ at $4^{\circ} \mathrm{C}$. MPO activity in the resuspended pellet was assayed by measuring the change in absorbance at $450 \mathrm{~nm}$ using o-dianisidine dihydrochloride and $1 \%$ hydrogen peroxide. The results are reported as MPO U/mg tissue. A unit of MPO activity is defined as that converting $1 \mu \mathrm{mol}$ of $\mathrm{H}_{2} \mathrm{O}_{2}$ to water in $1 \mathrm{~min}$ at $22^{\circ} \mathrm{C}$.

\section{Cytokine measurements}

The animals had a sample of their stomach removed on day 4 for analysis of cytokines. The specimens were stored at $-70^{\circ} \mathrm{C}$ until required for assay. The collected tissues were homogenized and processed as described by SafiehGarabedian et al. (22). The concentrations of tumor necrosis factor (TNF)- $\alpha$ and interleukin (IL)-1 $\beta$ were determined by using an enzyme-linked immunosorbent assay (ELISA), as described previously (20). Briefly, microtiter plates were coated overnight at $4{ }^{\circ} \mathrm{C}$ with an antibody against rat TNF- $\alpha$ or IL- $1 \beta(4 \mu \mathrm{g} / \mathrm{mL}$, DuoSet ELISA Development kit, R\&D Systems, USA; Catalog Nos. DY501 and DY510, respectively). After blocking the plates, the samples and standards were added at various dilutions in duplicate and incubated at $4^{\circ} \mathrm{C}$ for $24 \mathrm{~h}$. The plates were washed three times with buffer. After the plates were washed, biotinylated sheep polyclonal anti-TNF- $\alpha$ or anti-IL-1 $\beta$ (diluted 1:1000 with assay buffer containing 1\% bovine serum albumin) was added to the wells. After further incubation at room temperature for $1 \mathrm{~h}$, the plates were washed and $50 \mu \mathrm{L}$ avidin-conjugated horseradish peroxidase diluted 1:5000 was added to the wells. The color reagent o-phenylenediamine $(50 \mu \mathrm{L})$ was added 15 min later and the plates were incubated in the dark at $37^{\circ} \mathrm{C}$ for $15-20 \mathrm{~min}$. The enzyme reaction was stopped with
$\mathrm{H}_{2} \mathrm{SO}_{4}$ and absorbance was measured at $490 \mathrm{~nm}$. Values are reported as picograms of cytokines per milliliter $(\mathrm{pg} / \mathrm{mL})$.

\section{Statistical analysis}

Data are reported as means \pm SE. One-way ANOVA and the Student-Newman-Keuls test were used to determine statistical significance of differences between groups. For histological assessment, the Kruskal-Wallis nonparametric test was used, followed by the Dunn test for multiple comparisons. Differences were considered to be significant when $\mathrm{P}<0.05$.

\section{Results}

\section{ALD-induced gastric damage}

Oral administration of ALD once daily for 4 days caused damage to the epithelium of the corporal and antral mucosa of the stomach, leading to severe ulcers with white caps (Figure 1A). Histopathological evaluation confirmed the presence of hemorrhagic lesions and inflammation in the mucosa of the glandular stomach, reflecting true ulcer formation (Table 1 and Figure 2). Furthermore, ALD-treated rats showed decreased GSH levels compared with controls. Conversely, MDA levels were higher in the ALD-treated rats (Table 2). The ALD-treated rats also showed elevated MPO activity (see Figure 3 ), as well as elevated levels of TNF- $\alpha$ and IL-1 $\beta$ (see Figure 4).

\section{Gastroprotective effect of Lawesson's reagent against ALD-induced gastric damage}

Lawesson's reagent $(27 \mu \mathrm{mol} / \mathrm{kg})$ protected against ALD-induced macroscopic (Figure 1B) and microscopic gastric damage (Table 1 and Figure 2). It also decreased hemorrhagic damage, inflammatory cell infiltration, and epithelial cell loss induced by ALD (Table 1 and Figure 2). Furthermore, Lawesson's reagent prevented the ALDmediated reduction in GSH levels (Table 2) and increase in MDA expression in the gastric mucosa. It also significantly attenuated the ALD-induced increase in MPO activity (Figure 3 ), and TNF- $\alpha$ and IL-1 $\beta$ concentrations in gastric tissue (Figure 4).

\section{Role of $\mathrm{K}_{\mathrm{ATP}}$ channels in the gastroprotective effects of Lawesson's reagent}

To assess the contribution of $\mathrm{K}_{\mathrm{ATP}}$ channels to the protective effects of Lawesson's reagent, other groups of rats were pretreated with glibenclamide alone or with diazoxide. In Figure 5, we demonstrated that glibenclamide $(1 \mathrm{mg} / \mathrm{kg})$ alone, without diazoxide, reversed the gastroprotective effect of Lawesson's reagent against ALD-induced macroscopic gastric damage.

\section{Discussion}

$\mathrm{H}_{2} \mathrm{~S}$ has been identified as a modulator of many physiological processes, including neurotransmission 
A

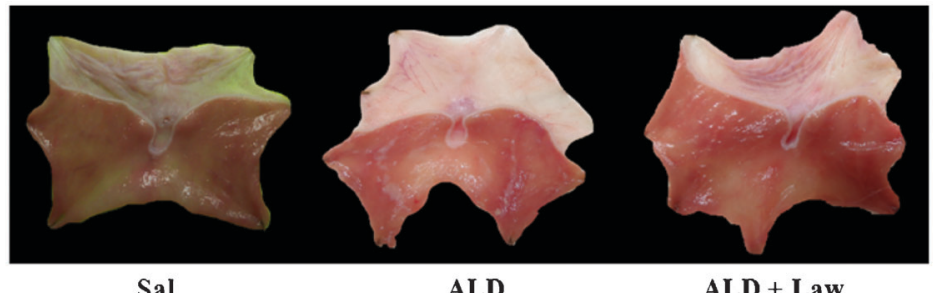

Sal
ALD

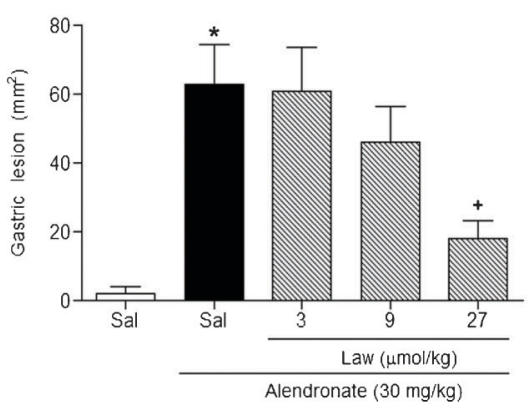

Figure 1. Lawesson's reagent reduces alendronateinduced gastric damage ( $A$ and $B$ ). Rats were treated by gavage with saline (Sal) or Lawesson's reagent (Law) for 4 days, followed by the administration of alendronate (ALD). Treatment with ALD produced widespread damage to the epithelium and the luminal surface was covered with cellular debris $(A)$ and Law decreased alendronateinduced gastropathy ( $A$ and $B$ ). The results are reported as means \pm SE for 5-7 animals per group. ${ }^{*} \mathrm{P}<0.05$ vs saline group; ${ }^{+} \mathrm{P}<0.05$ vs alendronate group (one-way ANOVA and Student-NewmanKeuls test).

(10), acute inflammation $(23,24)$, and pain $(25,26)$. Of particular relevance to the present study is that $\mathrm{H}_{2} \mathrm{~S}$ is known to contribute to the maintenance of gastric mucosal integrity against damage caused by NSAIDs (12) and ethanol (13). Therefore, we evaluated the protective effect of Lawesson's reagent, an $\mathrm{H}_{2} \mathrm{~S}$ donor, against ALD-induced gastric damage in rats.

We found that ALD causes severe gastric mucosal damage, accompanied by hemorrhage, infiltration of inflammatory cells, and loss of epithelial cells. Our finding that Lawesson's reagent decreased ALD-induced gastropathy is consistent with studies showing that the $\mathrm{H}_{2} \mathrm{~S}$ precursor, L-cysteine, or $\mathrm{H}_{2} \mathrm{~S}$ donors attenuate NSAIDor ethanol-induced gastropathy $(12,13)$. Together, these findings highlight an important role for $\mathrm{H}_{2} \mathrm{~S}$ in gastric protection.

The mechanism by which ALD causes mucosal injury has not been fully elucidated. However, ALD-induced neutrophil accumulation and subepithelial edema in the gastric mucosa have been shown to play major roles in the development of ulcers (27). Neutrophils are a potential source of oxygen-free radicals $(28,29)$ and are considered major effector cells in the tissue damage that occurs in several inflammatory diseases (30). When neutrophils are stimulated, MPO and proinflammatory cytokines are released, and granulocytes are activated, which promote cell death and gastric damage $(31,32)$. In the present study, the increases in TNF- $\alpha$ and IL1- $\beta$ levels, and in MPO activity in the gastric mucosa, reflect the impact of proinflammatory cytokines and neutrophil infiltration, respectively, in ALD-mediated gastric damage. There is evidence to suggest that $\mathrm{H}_{2} \mathrm{~S}$ inhibits leukocyte-endothelial cell adhesion $(23,33)$.

Because Lawesson's reagent inhibited the ALDinduced elevation in MPO activity, and TNF- $\alpha$ and IL-1 $\beta$ levels, our results suggest that the gastroprotective effect of an $\mathrm{H}_{2} \mathrm{~S}$ donor may be dependent on its inhibitory effect on neutrophil infiltration and the neutrophil-associated TNF- $\alpha$ and IL-1 $\beta$ response.

Results from several studies suggest that reactive oxygen species may contribute to ALD-induced gastric mucosal lesions $(16,34)$. This observation is consistent with our finding that ALD decreased GSH levels and increased MDA levels. The rise in the MDA level, an index

Table 1. Effect of Lawesson's reagent (Law, $27 \mu \mathrm{mol} / \mathrm{kg}$ ) on alendronate-induced microscopic gastric damage.

\begin{tabular}{lccccc}
\hline Experimental group & $\begin{array}{c}\text { Hemorrhagic } \\
\text { damage }(\text { score, 0-4) }\end{array}$ & $\begin{array}{c}\text { Edema } \\
\text { (score, 0-4) }\end{array}$ & $\begin{array}{c}\text { Epithelial cell } \\
\text { loss (score, 0-3) }\end{array}$ & $\begin{array}{c}\text { Inflammatory cells } \\
\text { (score, 0-3) }\end{array}$ & $\begin{array}{c}\text { Total } \\
(\text { score, 0-14) }\end{array}$ \\
\hline Saline & $0(0-1)$ & 0 & $0(0-1)$ & $0(0-1)$ & $1(0-3)$ \\
Alendronate & $3(2-4)^{*}$ & $2(1-3)^{*}$ & $3(2-3)^{*}$ & $3(2-3)^{*}$ & $10(7-12)^{*}$ \\
Law + alendronate & $1(0-1)^{+}$ & $1(0-2)$ & $1(0-1)^{+}$ & $1(0-1)^{+}$ & $4(0-5)^{+}$ \\
\hline
\end{tabular}

Data are reported as median with the minimum and maximum scores given in parentheses. The Kruskal-Wallis nonparametric test followed by the Dunn test were used for multiple comparisons of histological analyses ( $n=5$ rats per group). ${ }^{*} P<0.05$ vs control group (saline); ${ }^{+} \mathrm{P}<0.05$ vs alendronate group. 


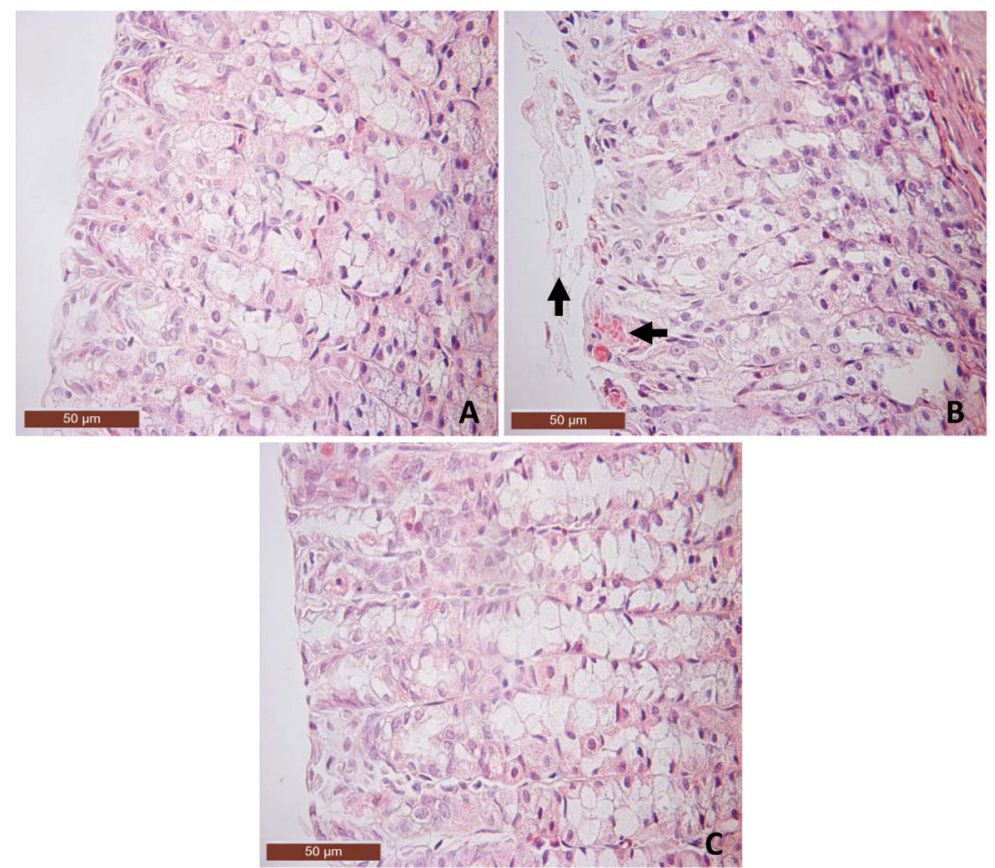

Figure 2. Histopathological alterations in the gastric mucosa of control and treated rats after 4 days of treatment. $A$, Saline control group showing gastric mucosal integrity (40X). $B$, Effect of alendronate on the gastric mucosa showing lesion in the superficial gastric glandular region with bleeding and loss of epithelial cells (arrows) (40X). C, Pretreatment with Lawesson's reagent $(27 \mu \mathrm{mol} / \mathrm{kg}$, po) showing a reduction in microscopic lesions caused by alendronate (40X). of lipid peroxidation, may also be partly due to free radicals generated by neutrophils (35). The importance of GSH in gastric defense was described by Szabo et al. (36), who showed that substances containing sulfhydryl radicals protect the gastric mucosa in a manner similar to that of prostaglandins (PGs) and that sulfhydryl group blockers, such as diethylmaleate and iodoacetamide, reverse the gastroprotective effect of PGF2 $\alpha$. They also demonstrated that GSH administration decreases ethanol-induced gastric damage by inactivating reactive oxygen species and products of lipid peroxidation (36). Thus, the ability of Lawesson's reagent to inhibit the effects of ALD on the GSH and MDA levels in the present study suggests that an $\mathrm{H}_{2} \mathrm{~S}$ donor may attenuate the redox state during ALD-induced gastric injury.

We have shown here that blockade of $\mathrm{K}_{\mathrm{ATP}}$ channels

Table 2. Effect of pretreatment with Lawesson's reagent (Law, $27 \mu \mathrm{mol} / \mathrm{kg}$ ) against alendronate-induced gastric damage in reduced glutathione (GSH) and malondialdehyde (MDA) levels in the gastric mucosa.

\begin{tabular}{lcc}
\hline Experimental group & $\begin{array}{c}\text { GSH } \\
(\mu \mathrm{g} / \mathrm{g} \text { tissue })\end{array}$ & $\begin{array}{c}\text { MDA } \\
(\mathrm{nmol} / \mathrm{g} \text { tissue })\end{array}$ \\
\hline Saline & $482.5 \pm 20.1$ & $71.5 \pm 2.6$ \\
Alendronate & $180.3 \pm 21.9^{*}$ & $121.1 \pm 4.3^{*}$ \\
Law + alendronate & $397.9 \pm 40.2^{+}$ & $78.4 \pm 7.6^{+}$ \\
\hline
\end{tabular}

Data are reported as means \pm SE for 5 rats per group. ${ }^{*} \mathrm{P}<0.05$, compared to control group. ${ }^{+} \mathrm{P}<0.05$, compared to alendronate group (ANOVA and Student-Newman-Keuls test were used for evaluation). with glibenclamide alone, without diazoxide, reversed Lawesson's reagent's protective effect against ALDinduced gastric damage. The participation of $\mathrm{K}_{\text {ATP }}$ channels in several models of gastric protection was previously described $(37,38)$. Other studies reported that glibenclamide pretreatment prevented the protective effects of NaHS and Lawesson's reagent against ethanol (13) and NSAIDs (12) induced macroscopic gastric damage, suggesting an involvement of $\mathrm{K}_{\text {ATP }}$ channels in $\mathrm{H}_{2} \mathrm{~S}$ gastroprotective effects.

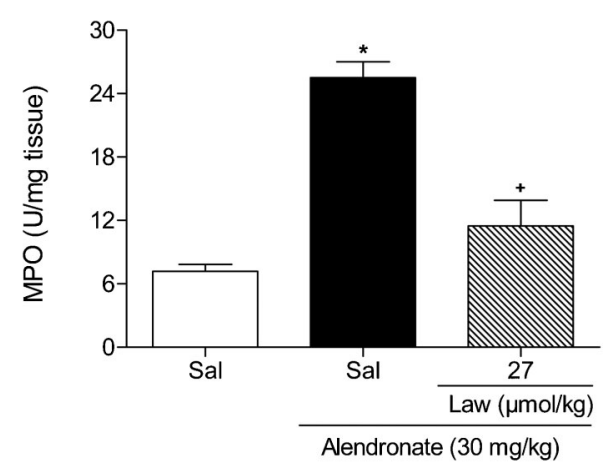

Figure 3. Effect of the Lawesson's reagent $(27 \mu \mathrm{mol} / \mathrm{kg})$ on gastric myeloperoxidase (MPO) activity in a rat model of alendronate-induced gastric damage. Rats were treated by gavage with saline (Sal) or Lawesson's reagent (Law) for 4 days, followed by the administration of alendronate. Results are reported as means \pm SE for 5-7 animals per group. ${ }^{*} \mathrm{P}<0.05 \mathrm{vs}$ control group; ${ }^{+} \mathrm{P}<0.05$ vs alendronate group (one-way ANOVA and Student-Newman-Keuls test). 

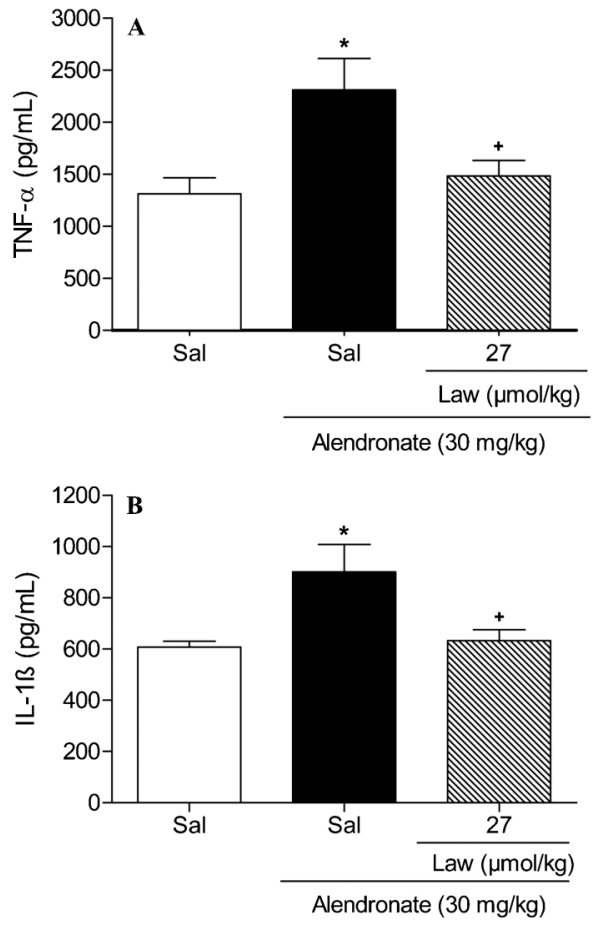

Figure 4. Treatment with Lawesson's reagent $(27 \mu \mathrm{mol} / \mathrm{kg})$ decreased concentration of TNF- $\alpha$ and $\mathrm{IL}-1 \beta$ ( $A$ and $B$, respectively) in alendronate-induced gastric damage. Rats were treated by gavage with Lawesson's reagent (Law) 30 min before alendronate $(30 \mathrm{mg} / \mathrm{kg})$ administration. The control group was treated with saline (Sal) only. All drugs were administered once daily for 4 days. Results are reported as means \pm SE for at least 5 rats per group. ${ }^{*} \mathrm{P}<0.05$, compared to control group. ${ }^{+} \mathrm{P}<0.05$, compared to alendronate group (one-way ANOVA and StudentNewman-Keuls test).

We showed that Lawesson's reagent, an $\mathrm{H}_{2} \mathrm{~S}$ donor, prevents ALD-induced gastric damage. We propose that Lawesson's reagent inhibits neutrophil infiltration and decreases damage secondary to the release of

\section{References}

1. Adami S, Mian M, Gatti $P$, Rossini $M$, Zamberlan $N$, Bertoldo $F$, et al. Effects of two oral doses of alendronate in the treatment of Paget's disease of bone. Bone 1994; 15: 415-417, doi: 10.1016/8756-3282(94)90818-4.

2. Francis RM. Oral bisphosphonates in the treatment of osteoporosis: a review. Curr Ther Res 1995; 56: 831-851, doi: 10.1016/0011-393X(95)85087-2.

3. Abdelmalek MF, Douglas DD. Alendronate-induced ulcerative esophagitis. Am J Gastroenterol 1996; 91: 1282-1283.

4. Blank MA, Ems BL, Gibson GW, Myers WR, Berman SK, Phipps RJ, et al. Nonclinical model for assessing gastric effects of bisphosphonates. Dig Dis Sci 1997; 42: 281-288, doi: 10.1023/A:1018849415297.

5. Graham DY, Malaty HM. Alendronate gastric ulcers. Aliment

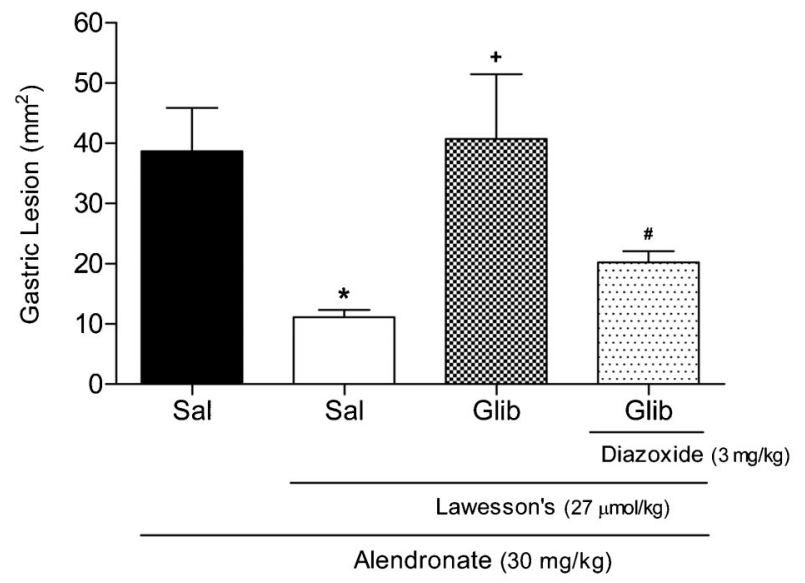

Figure 5. Effect of glibenclamide and diazoxide pretreatment on the protective effect of Lawesson's reagent on alendronateinduced gastric lesions in rats. Glibenclamide (Glib, $1 \mathrm{mg} / \mathrm{kg}$, ip) was injected 30 min before Lawesson's reagent $(27 \mu \mathrm{mol} / \mathrm{kg})$ or saline (Sal). Another group was treated in the same manner but diazoxide $(3 \mathrm{mg} / \mathrm{kg}, i p)+$ Glib $(1 \mathrm{mg} / \mathrm{kg})$ was administered. Rats were treated by gavage with Lawesson's reagent 30 min before alendronate $(30 \mathrm{mg} / \mathrm{kg})$ administration. The control group was treated with alendronate only. All drugs were administered once daily for 4 days. Results are reported as means \pm SE for at least 5 rats per group. ${ }^{*} \mathrm{P}<0.05$, compared to control group. ${ }^{+} \mathrm{P}<0.05$, compared to Lawesson's reagent + alendronate group. ${ }^{\#} \mathrm{P}<0.05$, compared to Glib + Lawesson's reagent+alendronate group (one-way ANOVA and Student-Newman-Keuls test).

proinflammatory cytokines and elevations in oxidative stress. Our data support the hypothesis that the activation of $\mathrm{K}_{\text {ATP }}$ channels is of primary importance.

\section{Acknowledgments}

The authors gratefully acknowledge the financial support from Research Foundation for the Estado do Piauí (FAPEPI) and CNPq.
Pharmacol Ther 1999; 13: 515-519, doi: 10.1046/j.13652036.1999.00488.x.

6. Lanza F, Schwartz H, Sahba B, Malaty HM, Musliner T, Reyes R, et al. An endoscopic comparison of the effects of alendronate and risedronate on upper gastrointestinal mucosae. Am J Gastroenterol 2000; 95: 3112-3117, doi: 10.1111/j.1572-0241.2000.03258.x.

7. Graham DY. Excess gastric ulcers are associated with alendronate therapy. Am J Gastroenterol 1998; 93: 13951396, doi: 10.1111/j.1572-0241.1998.01395.x.

8. Milby $\mathrm{TH}$, Baselt RC. Hydrogen sulfide poisoning: clarification of some controversial issues. Am J Ind Med 1999; 35: 192195, doi: 10.1002/(SICI)1097-0274(199902)35:2<192::AIDAJIM11>3.0.CO;2-C. 
9. Abe $\mathrm{K}$, Kimura $\mathrm{H}$. The possible role of hydrogen sulfide as an endogenous neuromodulator. J Neurosci 1996; 16: 1066-1071.

10. Wang R. Two's company, three's a crowd: can $\mathrm{H}_{2} \mathrm{~S}$ be the third endogenous gaseous transmitter? FASEB J 2002; 16 : 1792-1798, doi: 10.1096/fj.02-0211hyp.

11. Boehning D, Snyder SH. Novel neural modulators. Annu Rev Neurosci 2003; 26: 105-131, doi: 10.1146/annurev.neuro.26.041002.131047.

12. Fiorucci S, Antonelli E, Distrutti E, Rizzo G, Mencarelli A, Orlandi $S$, et al. Inhibition of hydrogen sulfide generation contributes to gastric injury caused by anti-inflammatory nonsteroidal drugs. Gastroenterology 2005; 129: 12101224, doi: 10.1053/j.gastro.2005.07.060.

13. Medeiros JV, Bezerra VH, Gomes AS, Barbosa AL, LimaJunior RC, Soares PM, et al. Hydrogen sulfide prevents ethanol-induced gastric damage in mice: role of ATPsensitive potassium channels and capsaicin-sensitive primary afferent neurons. J Pharmacol Exp Ther 2009; 330: 764-770, doi: 10.1124/jpet.109.152801.

14. Wallace JL, Dicay M, McKnight W, Martin GR. Hydrogen sulfide enhances ulcer healing in rats. FASEB J 2007; 21: 4070-4076, doi: 10.1096/fj.07-8669com.

15. Kanatsu K, Aihara E, Okayama M, Kato S, Takeuchi K. Mucosal irritative and healing impairment action of risedronate in rat stomachs: comparison with alendronate. $J$ Gastroenterol Hepatol 2004; 19: 512-520, doi: 10.1111/ j.1440-1746.2003.03314.x.

16. Costa NR, Silva RO, Nicolau LA, Lucetti LT, Santana AP, Aragão KS, et al. Role of soluble guanylate cyclase activation in the gastroprotective effect of the $\mathrm{HO}-1 / \mathrm{CO}$ pathway against alendronate-induced gastric damage in rats. Eur J Pharmacol 2013; 700: 51-59, doi: 10.1016/j.ejphar.2012.12.007.

17. Sedlak J, Lindsay RH. Estimation of total, protein-bound, and nonprotein sulfhydryl groups in tissue with Ellman's reagent. Anal Biochem 1968; 25: 192-205, doi: 10.1016/ 0003-2697(68)90092-4.

18. Mihara M, Uchiyama M. Determination of malonaldehyde precursor in tissues by thiobarbituric acid test. Anal Biochem 1978; 86: 271-278, doi: 10.1016/0003-2697(78)90342-1.

19. Bradley PP, Christensen RD, Rothstein G. Cellular and extracellular myeloperoxidase in pyogenic inflammation. Blood 1982; 60: 618-622.

20. Cunha FQ, Boukili MA, da Motta JI, Vargaftig BB, Ferreira $\mathrm{SH}$. Blockade by fenspiride of endotoxin-induced neutrophil migration in the rat. Eur J Pharmacol 1993; 238: 47-52, doi: 10.1016/0014-2999(93)90503-A.

21. Laine L, Weinstein WM. Histology of alcoholic hemorrhagic "gastritis": a prospective evaluation. Gastroenterology 1988; 94: 1254-1262.

22. Safieh-Garabedian B, Poole S, Allchorne A, Winter J, Woolf CJ. Contribution of interleukin-1 beta to the inflammationinduced increase in nerve growth factor levels and inflammatory hyperalgesia. $\mathrm{Br} J$ Pharmacol 1995; 115: 1265-1275, doi: 10.1111/j.1476-5381.1995.tb15035.x.

23. Zanardo RC, Brancaleone V, Distrutti E, Fiorucci S, Cirino $G$, Wallace JL. Hydrogen sulfide is an endogenous modulator of leukocyte-mediated inflammation. FASEB $J$ 2006; 20: 2118-2120, doi: 10.1096/fj.06-6270fje.

24. Dal-Secco D, Cunha TM, Freitas A, Alves-Filho JC, Souto FO, Fukada SY, et al. Hydrogen sulfide augments neutrophil migration through enhancement of adhesion molecule expression and prevention of CXCR2 internalization: role of ATP-sensitive potassium channels. J Immunol 2008; 181: 4287-4298.

25. Distrutti E, Sediari L, Mencarelli A, Renga B, Orlandi S, Russo $\mathrm{G}$, et al. 5-Amino-2-hydroxybenzoic acid 4-(5-thioxo-5H[1,2]dithiol-3yl)-phenyl ester (ATB-429), a hydrogen sulfidereleasing derivative of mesalamine, exerts antinociceptive effects in a model of postinflammatory hypersensitivity. $J$ Pharmacol Exp Ther 2006; 319: 447-458, doi: 10.1124/ jpet.106.106435.

26. Cunha TM, Dal-Secco D, Verri WA Jr, Guerrero AT, Souza GR, Vieira SM, et al. Dual role of hydrogen sulfide in mechanical inflammatory hypernociception. Eur J Pharmacol 2008; 590: 127-135, doi: 10.1016/j.ejphar.2008.05.048.

27. Wallace JL, Dicay M, McKnight W, Bastaki S, Blank MA. Nbisphosphonates cause gastric epithelial injury independent of effects on the microcirculation. Aliment Pharmacol Ther 1999; 13: 1675-1682, doi: 10.1046/j.1365-2036.1999.00658.x.

28. Parks DA, Granger DN. Ischemia-reperfusion injury: a radical view. Hepatology 1988; 8: 680-682, doi: 10.1002/ hep. 1840080341.

29. Sullivan GW, Sarembock IJ, Linden J. The role of inflammation in vascular diseases. J Leukoc Biol 2000; 67: 591-602.

30. Kettle AJ, Winterbourn CC. Myeloperoxidase: a key regulator of neutrophil oxidant production. Redox Report 1997; 3: 3-15.

31. Yamaguchi K, Motegi K, Iwakura Y, Endo Y. Involvement of interleukin-1 in the inflammatory actions of aminobisphosphonates in mice. Br J Pharmacol 2000; 130: 1646-1654, doi: $10.1038 /$ sj.bjp.0703460.

32. Thiebaud D, Sauty A, Burckhardt P, Leuenberger P, Sitzler $\mathrm{L}$, Green JR, et al. An in vitro and in vivo study of cytokines in the acute-phase response associated with bisphosphonates. Calcif Tissue Int 1997; 61: 386-392, doi: 10.1007/ s002239900353.

33. Fiorucci S, Distrutti E, Cirino G, Wallace JL. The emerging roles of hydrogen sulfide in the gastrointestinal tract and liver. Gastroenterology 2006; 131: 259-271, doi: 10.1053/ j.gastro.2006.02.033.

34. Sener G, Paskaloglu K, Kapucu C, Cetinel S, Contuk G, Ayanoglu-Dulger G. Octreotide ameliorates alendronateinduced gastric injury. Peptides 2004; 25: 115-121, doi: 10.1016/j.peptides.2003.11.017.

35. Szabo S, Trier JS, Frankel PW. Sulfhydryl compounds may mediate gastric cytoprotection. Science 1981; 214: 200202, doi: 10.1126/science.7280691.

36. Szabo S, Nagy L, Plebani M. Glutathione, protein sulfhydryls and cysteine proteases in gastric mucosal injury and protection. Clin Chim Acta 1992; 206: 95-105, doi: 10.1016/ 0009-8981(92)90010-N.

37. Medeiros JVR, Gadelha GG, Lima SJ, Garcia JA, Soares PMG, Santos AA, et al. Role of the NO/cGMP/ $\mathrm{K}(\mathrm{ATP})$ pathway in the protective effects of sildenafil against ethanol-induced gastric damage in rats. $\mathrm{Br} J$ Pharmacol 2008; 153: 721-727, doi: 10.1038/sj.bjp.0707605.

38. Gomes AS, Gadelha GG, Lima SJ, Garcia JA, Medeiros JVR, Havt A, et al. Gastroprotective effect of heme-oxygenase $1 /$ biliverdin/CO pathway in ethanol-induced gastric damage in mice. Eur J Pharmacol 2010; 642: 140-145, doi: 10.1016/ j.ejphar.2010.05.023. 